\title{
Endoscopic Approach to Esophageal Leiomyomas: Single Center Results
}

\author{
Özofagus Leyomiyomlarında Endoskopik Yaklaşım: Tek Merkez Sonuçları
}

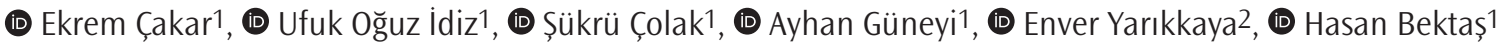 \\ 1 University of Health Sciences, İstanbul Training and Research Hospital, Clinic of General Surgery, İstanbul, Turkey \\ 2University of Health Sciences, İstanbul Training and Research Hospital, Clinic of Pathology, İstanbul, Turkey
}

\begin{abstract}
Introduction: Leiomyoma is the most common esophageal benign lesion. There are many treatment methods from endoscopic treatment methods to surgery in the treatment of leiomyoma. In this study, we evaluated the results of our patients who underwent endoscopic mucosal (EMR) and submucosal dissection (ESD) due to esophageal leiomyoma.
\end{abstract}

Methods: A total of 18 patients who underwent EMR or ESD protocol with the diagnosis of esophageal leiomyoma were included in the study and age, gender, radiological imaging results, endoscopic ultrasonography results, treatment method, pathology results, and outpatient follow-up data of the patients were recorded following retrospective examination of the patient files.

Results: The mean age of the patients was $52.7 \pm 13.36$ years, and the ratio of female/male was $1 / 1.25$. Incidental lesions were found during endoscopic procedures in six patients (33.3\%) due to dyspeptic complaints and in three patients (16.7\%) due to dysphagia and during computed tomography in the remaining nine patients (50\%) for various reasons. For treatment, three patients underwent EMR, and 15 patients underwent ESD. One patient had a hemorrhage controlled by endoscopic intervention, and no other complications were observed after treatment.

Conclusion: It should be kept in mind that ESD and EMR, which are among the endoscopic treatment methods in the treatment of esophageal leiomyoma, could be safely applied in experienced hands.

Keywords: Esophagus, leiomyoma, endoscopic mucosal resection, endoscopic submucosal dissection

\section{$\ddot{0} Z$}

Amaç: En sık gözlenen özofagus benign lezyonları leiomiyomlardır. Leiomiyomların tedavisinde endoskopik tedavi yöntemlerinden cerrahiye kadar birçok tedavi yöntemi bulunmaktadır. Biz de bu çalışmamızda özofagus leiomiyomu sebebiyle endoskopik mukozal (EMR) ve submukozal rezeksiyon (ESD) yapılan hastalarımızın sonuçlarını değerlendirdik.

Yöntemler: Özofageal leiomiyom tanısı ile EMR veya ESD protokolü uygulanan toplam 18 hasta çalıșmaya dahil edilmiş olup hastaların hastane dosyalarının retrospektif olarak incelenmesi sonucunda hastaların yașları, cinsiyetleri, radyolojik görüntüleme sonuçları, endoskopik ultrasonografi sonuçları, uygulanan tedavi yöntemi, patoloji sonuçları ve hastaların poliklinik takip notları kayıt altına alınmıștır.

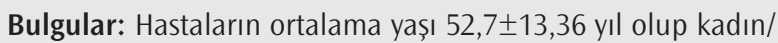
erkek oranı 1/1,25'tir. Hastaların 6'sında $(\% 33,3)$ dispeptik şikayetler nedeniyle yapılan tetkiklerde, 3’ünde $(\% 16,7)$ disfaji nedeniyle yapılan endoskopik girișimler sırasında, diğer 9 hastada (\%50) ise çeșitli sebeplerle çekilen bilgisayarlı tomografiler sırasında insidental olarak lezyonlar bulunmuștur. Tedavi için 3 hastaya EMR, 15 hastaya ise ESD uygulanmıştır. Tedavi sonrası 1 hastada endoskopik müdahale ile durdurulan kanama mevcut olup bașka bir komplikasyon gözlenmemiștir.

Sonuç: Özofagus leiomiyomlarının tedavisinde endoskopik tedavi yöntemlerinden olan ESD ve EMR'nin tecrübeli ellerde güvenle uygulanabileceği akılda bulundurulmalıdır.

Anahtar Kelimeler: Özofagus, leiomiyom, endoskopik mukozal rezeksiyon, endoskopik submukozal rezeksiyon

\section{Introduction}

Benign lesions of the esophagus are rare lesions and constitute less than $1 \%$ of all esophageal lesions, and 2/3 of these lesions are leiomyomas, and the rest are polyps and cysts (1). Although esophageal leiomyomas are seen at any age from the age of 20 to the age of 80 , they are most frequently observed between the ages of 40-50 and show similar morphological features as the leiomyomas observed in other organs. Leiomyomas generally originate from muscularis propria and can grow up to $30 \mathrm{~cm}$ intraluminally and extraluminally (2-4).
Address for Correspondence/Yazışma Adresi: Ufuk Oğuz İdiz MD, University of Health Sciences, İstanbul Training and

Research Hospital, Clinic of General Surgery, İstanbul, Turkey

Phone: +902124596000 E-mail: oguzidiz@yahoo.com ORCID ID: orcid.org/0000-0002-8462-7809

Cite this article as/Atıf: Çakar E, İdiz UO, Çolak Ș, Güneyi A, Yarıkkaya E, Bektaș H. Endoscopic Approach to Esophageal Leiomyomas: Single Center Results. İstanbul Med J 2020; 21(1): 33-6.

(c) Copyright 2020 by the Istanbul Training and Research Hospital/istanbul Medical Journal published by Galenos Publishing House.

(C) Telif Hakkı 2020 istanbul Ĕgitim ve Araștırma Hastanesi/Istanbul Tıp Dergisi, Galenos Yayınevi tarafından basıImıștır.

Received/Geliș Tarihi: 07.10.2019 Accepted/Kabul Tarihi: 12.12.2019 
There are many options in the treatment of benign esophageal lesions, from endoscopic interventions to surgical treatment $(1,5)$. While thoracotomy was the preferred treatment method in the 1990's, later thoracoscopy and laparoscopy replaced it as the more frequently applied treatments (6-9). The developments in endoscopy in the last few decades have caused an increase in the frequency of using endoscopic treatments (10). Endoscopic mucosal resection (EMR) and endoscopic submucosal dissection (ESD), which are among the endoscopic treatment options, can be used safely in experienced hands in benign and earlystage malignant tumors $(5,10,11)$.

In this study, we evaluated the results of our endoscopic treatments for benign esophageal lesions.

\section{Methods}

Our study started after obtaining approval from the University of Health Sciences, İstanbul Training and Research Hospital Local Clinical Research Ethics Committee (decision no: 2017, date:11/10/2019), and 38 patients who underwent standard EMR or ESD protocol with the diagnosis of an esophageal mass in the endoscopy unit between 2013-2017 constitute the universe of our study. Informed consent was obtained from all patients before the study. The patients with a pathological diagnosis of leiomyoma were included in the study. Patients with malignant and other benign esophageal pathologies or patients with incomplete data in hospital records were excluded from the study.

The ages, genders, endoscopic ultrasonography (EUS) results, treatment methods, pathology results, and outpatient follow-up data of 18 patients included in the study were recorded. Age and tumor size analysis of the patients were calculated as mean and standard deviation (SD).

\section{Statistical Analysis}

Statistical analysis of the data of our study was performed with SPSS version 21.0. Continuous data of the patients were given as mean \pm SD, and categorical data were reported as a percentage.

\section{Results}

The mean age of 18 patients in our study was $52.7 \pm 13.36$ years, and female/male $(F / M)$ ratio was $1 / 1.25$. Lesions were detected during endoscopic procedures due to dyspeptic complaints in six patients (33.3\%) and dysphagia in three patients (16.7\%). In nine patients (50\%), incidental lesions were found during thoracoabdominal computed tomography (CT). All patients underwent EUS and thoracoabdominal CT before treatment. In only two of the patients, an endoscopic biopsy was performed to clarify the diagnosis of leiomyoma in CT and EUS, and the pathology results were leiomyoma. Considering the treatment methods, EMR was applied in three patients, and ESD was applied in 15 patients, and the mean size of the excised lesions was $11.1 \pm 6.26 \mathrm{~mm}$. The mean diameter of the lesions of patients with symptomatic leiomyoma was $23.3 \mathrm{~mm}$. Considering the location of the lesions, there was one lesion in the cervical esophagus, four lesions in the abdominal esophagus, and 13 lesions in the thoracic esophagus (Table 1).

When the post-treatment complications were evaluated, hemorrhage developed in one patient and was taken under control by using

endoscopic cauterization and $9 \mathrm{~mm}$ "through the scope clip" (Quick clip $^{\circledR}$, Olympus, Hamburg, Germany). Perforation and mortality were not observed in any patient. Malign transformation or recurrence was not observed in the mean follow-up of $3.8 \pm 1.85$ years.

\section{Discussion}

The successful surgical operation was performed approximately 65 years after esophageal leiomyomas were described by Wirshow in the $19^{\text {th }}$ century $(12,13)$. With the popularization of minimally invasive interventions over the years, thoracoscopic interventions and then endoscopic interventions were initiated in the leiomyoma treatment. While the F/M ratio was reported to be equal in some studies, this ratio was reported as $1 / 1.9$ in some studies $(1,14)$. In our study, leiomyomas were found more frequently in men. The mean age of diagnosis in studies was reported to be in the $4^{\text {th }}-5^{\text {th }}$ decade, and our study had a similar mean age with literature $(1,10,14)$.

Leiomyomas are usually incidentally detected due to being slow-growing tumoral lesions on the esophageal wall $(15,16)$. The most common symptoms are dysphagia, chest and retrosternal pain, regurgitation, epigastric pain, dyspnea, and weight loss. In a study, it was reported that there was a correlation between the size of leiomyoma and the presence of symptoms, and the mean tumor diameter in symptomatic patients was reported to be $5.3 \mathrm{~cm}$ (4). In our study, endoscopy was performed in three patients due to dysphagia, and the mean tumor size of these patients was $23.3 \mathrm{~mm}$. Leiomyomas are usually located in the middle 2/3 part of the esophagus (17). In our study, in accordance with the literature, leiomyomas were detected in the thoracic esophagus in the majority of patients.

Table 1. Results of patients with esophageal leiomyomas

\begin{tabular}{|c|c|c|c|c|c|}
\hline Gender & Age & ESD/EMR & $\begin{array}{l}\text { Diameter } \\
(\mathrm{mm})\end{array}$ & Pathology & Location \\
\hline M & 31 & ESD & 6 & Leiomyoma & Abdominal \\
\hline $\mathrm{F}$ & 51 & ESD & 25 & Leiomyoma & Thoracic \\
\hline $\mathrm{F}$ & 57 & ESD & 15 & Leiomyoma & Thoracic \\
\hline M & 51 & ESD & 8 & Leiomyoma & Thoracic \\
\hline M & 48 & EMR & 8 & Leiomyoma & Thoracic \\
\hline M & 61 & EMR & 7 & Leiomyoma & Cervical \\
\hline $\mathrm{F}$ & 65 & ESD & 20 & Leiomyoma & Thoracic \\
\hline M & 35 & ESD & 10 & Leiomyoma & Thoracic \\
\hline $\mathrm{F}$ & 52 & EMR & 16 & Leiomyoma & Thoracic \\
\hline $\mathrm{F}$ & 61 & ESD & 12 & Leiomyoma & Thoracic \\
\hline M & 60 & ESD & 5 & Leiomyoma & Thoracic \\
\hline M & 58 & ESD & 8 & Leiomyoma & Thoracic \\
\hline M & 55 & ESD & 10 & Leiomyoma & Thoracic \\
\hline F & 72 & EMR & 5 & Leiomyoma & Abdominal \\
\hline M & 63 & ESD & 6 & Leiomyoma & Thoracic \\
\hline M & 70 & ESD & 8 & Leiomyoma & Abdominal \\
\hline $\mathrm{F}$ & 20 & ESD & 7 & Leiomyoma & Thoracic \\
\hline $\mathrm{F}$ & 40 & ESD & 25 & Leiomyoma & Abdominal \\
\hline
\end{tabular}


Chest X-ray, barium esophagography, endoscopy, EUS, CT, and magnetic resonance are among the imaging methods used in the diagnosis of esophageal leiomyomas (1,18-20). The chest X-ray shows a mediastinal mass, and barium esophagography shows a filling defect. Leiomyomas are seen as homogeneous, round or lobulated soft tissue masses in tomography (20). In endoscopy, they are observed as free-moving masses under the intact mucosa. EUS is one of the most useful methods for diagnosis. In this method, the mass can be distinguished as intramural, homogeneous, hypoechoic, and well-circumscribed $(19,20)$.

In cases where leiomyoma is suspected, if the mucosa is intact during endoscopy, it is recommended to avoid biopsy due to the possibility of being non-diagnostic and increasing surgical complications $(1,18,21)$. However, it is not always possible to distinguish leiomyomas from other submucosal lesions despite all imaging methods (21). In our study, ESD was applied to two patients after diagnosis by endoscopic biopsy because of the suspicion of imaging methods.

EMR and ESD have complications due to being invasive procedures. latrogenic injuries, which have an essential place in esophageal perforations, can be observed during endoscopic treatments of leiomyomas (22). Compared with EMR, hemorrhage, and perforation rates are higher in ESD. Many of these complications are associated with surgeon-dependent factors $(23,24)$. Depending on the experience, hemorrhage and perforations can be managed with clips and coagulation (25). In our study, hemorrhage occurred in only one patient who underwent ESD, and it was stopped using both coagulation and clips, and no patient had perforation.

\section{Conclusion}

As a result, while choosing the treatment to be used in the treatment of esophageal leiomyomas, ESD and EMR performed with endoscopic methods can be successfully applied with low complication rates in experienced hands instead of treatment methods with higher morbidity such as surgery.

Acknowledgment: This research did not receive any specific grant from funding agencies in the public, commercial, or not for profit sectors.

Ethics Committee Approval: Our study started after obtaining approval from the University of Health Sciences, İstanbul Training and Research Hospital Local Clinical Research Ethics Committee (decision no: 2017, date:11/10/2019).

Informed Consent: Informed consent was obtained from all patients before the study.

Peer-review: Externally peer-reviewed.

Author Contributions: Surgical and Medical Practices - E.C.., U.O.I., \$.Ç., A.G., E.Y., H.B.; Concept - E.C.., U.O.I., S..Ç.; Design - E.Ç., A.G.; Data Collection and/or Processing - E.Ç., U.O.I., Ş.Ç., A.G., E.Y.; Analysis and/ or Interpretation - A.G., E.Y., H.B.; Literature Search - E.Ç., U.O.I., S..Ç.; Writing Manuscript - E.Ç., U.O.I., Ş.C.., A.G., E.Y., H.B.

Conflict of Interest: No conflict of interest was declared by the authors.
Financial Disclosure: The authors declared that this study received no financial support.

\section{References}

1. Jiang W, Rice TW, Goldblum JR. Esophageal leiomyoma: experience from a single institution. Dis Esophagus 2013; 26: 167-74.

2. Seremetis MG, Lyons WS, DeGuzman VC, Peabody JW Jr. Leiomyomata of the esophagus. An analysis of 838 cases. Cancer 1976; 38: 2166-77.

3. Wang L, Ren W, Zhang Z, Yu J, Li Y, Song Y. Retrospective study of endoscopic submucosal tunnel dissection (ESTD) for surgical resection of esophageal leiomyoma. Surg Endosc 2013; 27: 4259-66.

4. Mutrie CJ, Donahue DM, Wain JC, Wright CD, Gaissert HA, Grillo HC, et al. Esophageal leiomyoma: A 40-year experience. Ann Thorac Surg 2005; 79: $1122-5$

5. Buyruk M, Vardar R. Endoskopik mukozal rezeksiyon ve endoskopik submukozal diseksiyon: Kime? Ne zaman? Güncel Gastroenteroloji 2018; 22: 7-17.

6. Bonavina L, Segalin A, Rosati R, Pavanello M, Peracchia A. Surgical therapy of esophageal leiomyoma. J Am Coll Surg 1995; 181: 257-62.

7. Choi SH, Kim YT, Han KN, Ra YJ, Kang CH, Sung SW, et al. Surgical management of the esophageal leiomyoma: Lessons from a retrospective review. Dis Esophagus 2011; 24: 325-9.

8. Bardini R, Segalin A, Ruol A, Pavanello M, Peracchia A. Videothoracoscopic enucleation of esophageal leiomyoma. Ann Thorac Surg 1992; 54: 576-7.

9. Izumi Y, Inoue H, Endo M. Combined endoluminal-intracavitary thoracoscopic enucleation of leiomyoma of the esophagus. A new method. Surg Endosc 1996; 10: 457-8.

10. Sun LJ, Chen X, Dai YN, Xu CF, Ji F, Chen LH, et al. Endoscopic ultrasonography in the diagnosis and treatment strategy choice of esophageal leiomyoma. Clinics (Sao Paulo) 2017; 72: 197-201.

11. Cakar E, Bektas H, Duzkoylu Y, Bayrak S, Pasaoglu E, Colak S, et al. Benign cysts and tumors of esophagus: Case series and review of the literature. SurgChron 2013; 18: 151-4.

12. Kramer M D, Gibb S P, Ellis F H Jr. Giant leiomyoma of esophagus. J Surg Oncol 1986; 33: 166-9.

13. Postlethwait RW, Musser AW. Changes in the esophagus in 1000 autopsy specimens. J Thorac Cardiovasc Surg 1974; 68: 953-6.

14. Hatch G F 3rd, Wertheimer-Hatch L, Hatch K F, Davis GB, Blanchard DK, Foster RS Jr, et al. Tumors of the esophagus. World J Surg 2000; 24: 401-11.

15. Priego P, Lobo E, Alonso N, Gil Olarte MA, Pérez de Oteyza J, Fresneda V. Surgical treatment of esophageal leiomyoma: An analysis of our experience. Rev Esp Enferm Dig 2006; 98: 350-8.

16. Roviaro GC, Maciocco M, Varoli F, Rebuffat C, Vergani C, Scarduelli A. Videothoracoscopic treatment of oesophageal leiomyoma. Thorax 1998; 53: 190-2.

17. Wang Y-j, Zhang R, Ouyang Z, Zhang D, Wang L. Diagnosis and surgical treatment of esophageal leiomyoma. Zhonghua zhong liu za zhi .Chinese J Oncol 2002; 24: 394-6.

18. Pompeo E, Francioni F, Pappalardo G, Trentino P, Crucitti G, Ricci C. Giant leiomyoma of the esophagus and cardia. Diagnostic and therapeutic considerations: Case report and literature review. Scand Cardiovasc J 1997; 31: 361-4.

19. Rice T W. Benign esophageal tumors: Esophagoscopy and endoscopic esophageal ultrasound. Semin Thorac Cardiovasc Surg 2003; 15: 20-6. 
20. Jang K M, Lee KS, Lee S J, Kim EA, Kim TS, Han D, et al. The spectrum of benign esophageal lesions: imaging findings. Korean J Radiol 2002; 3: 199-210.

21. Lee L S, Singhal S, Brinster C J, Marshall B, Kochman ML, Kaiser LR, et al. Current management of esophageal leiomyoma. J Am Coll Surg 2004; 198 : $136-46$.

22. Isik A, Firat D, Peker K, Sayar I, Idiz O, Soytürk M. A case report of esophageal perforation: Complication of nasogastric tube placement. Am J Case Rep 2014; 15: 168-71.
23. Kim SH, Moon JS, Youn YH, Lee KM, Lee SJ. Management of the complications of endoscopic submucosal dissection. World J Gastroenterol 2011; 17: 3575-9.

24. Schlachterman A, Yang D, Goddard A, Gotoda T, Draganov PV. Perspectives on endoscopic submucosal dissection training in the United States: A survey analysis. Endosc Int Open 2018; 6: 399-409.

25. Friedel D, Stavropoulos SN. Introduction of endoscopic submucosal dissection in the West. World J Gastrointest Endosc 2018; 10: 225-38. 